\title{
A Critical Discourse Analysis of Mind Control Strategies in George Orwell's Nineteen Eighty-Four
}

\author{
Khalid S. T. Abdu ${ }^{1} \&$ Ayman F. Khafaga ${ }^{1 \& 2}$ \\ ${ }^{1}$ Department of English, College of Science and Humanities, Prince Sattam bin Abdulaziz University, Saudi \\ Arabia \\ ${ }^{2}$ Department of English, Faculty of Arts and Humanities, Suez Canal University, Egypt \\ Correspondence: Khalid Sultan Abdu, Department of English Language, College of Science and Humanities at \\ Al- Aflaj, Prince Sattam bin Abdulaziz University, P.O. Box 710, Al-Aflaj 11912, Saudi Arabia. E-mail: \\ k.abdu@psau.edu.sa
}

Received: October 1, 2019 Accepted: October 27, 2019 Online Published: November 12, 2019

doi:10.5539/ijel.v9n6p421 URL: https://doi.org/10.5539/ijel.v9n6p421

\begin{abstract}
This paper attempts a Critical Discourse Analysis (CDA) of mind control strategies in George Orwell's Nineteen Eighty-Four (1948). More specifically, the paper tries to shed lights on the discursive practices that are used to control the public's minds in a way that guarantees complete compliance to a specific ideology. Orwell's novel is one of the distinguished narratives in the twentieth century. This type of fiction has always been a site of power conflict reflecting the atrocities committed against the public by those in power. The main objective of the paper is to uncover the strategies employed to control minds. It tries to explore the extent to which these discursive tactics are used to direct attitudes and change behavior. The paper therefore attempts to offer a linguistic shield against the manipulative use of language. In doing so, the paper adopts CDA in the analysis of the selected data. Some CDA's strategies have been marked and analyzed as indicative in exposing the extent to which language is biased towards mind control. Three main strategies are discussed here: simplification, euphemism and morphologicalization. The paper reveals that specific discursive practices have manipulatively been used by the elites to reformulate the ideological responses and attitudinal thinking of the masses.
\end{abstract}

Keywords: mind control, critical discourse analysis, simplification, euphemism, morphologicalization, Orwell's Nineteen Eighty-four

\section{Introduction}

Using language to control minds is one of the major themes presented in Orwell's Nineteen Eighty-Four. The novel is considered one of the most popular dystopian narratives in the twentieth century, in which language is employed in the context of ideological politics to communicate power, dominance and control. This paper attempts a critical discourse analysis to explore the extent to which language is ideologically utilized to manipulate rather than to illuminate. Within Orwellian perspective, language is seen as a means of controlling minds and shaping attitudes. In Nineteen Eighty-Four, Oceania's citizens are ruled by a socialist system under the name of the Party headed by a powerful leader called Big Brother. This system employs different tactics to restrict the freedom of the public. In Orwell's Oceania, different types of linguistic manipulation have been practiced against the masses. This manipulative linguistics is known as "Orwellian linguistics" (Hodge \& Fowler, 1979) which is developed through the passage of time to be Critical Discourse Analysis (CDA). Here lies the relevance of CDA to the study of mind control in discourse in general, and in the selected novel in particular. As such, the present paper is supposed to make a connection between the narrative and the linguistic within the context of politics.

The objectives of this paper are: first, to provide a critical discourse analysis of the strategies employed to achieve mind control, which enables us to rethink the discursive practices of others so as to be able to fight all types of manipulation; second, to explore the ways through which language is subjugated to issues of power that fit the goals of its users. This paper, therefore, tries to offer a linguistic shield that resists compliance to any mischievous discursive practices. This goal is targeted within the theoretical and analytical light of Critical Discourse Analysis as discussed in the writings of Fairclough (1989, 1995); Fairclough and Wodak (1997); van Dijk (1993, 1996, $2000,2001)$, to mention just a few names. CDA offers a way of understanding the role of language in the production of dominance and inequality. Its main concern is to show how discourse reflects power and asserts it as 
it focuses on the interests of the powerful which is realized on the expense of the powerless in societies.

This paper addresses the following research questions: first, what are the different CDA's strategies employed to manipulate minds in Orwell's Nineteen Eighty-Four? Second, how does CDA reveal hidden tactics of power abuse and mind control in the novel under investigation? Third, to what extent is CDA theoretically and analytically relevant to the study of mind control in the selected novel? The significance of the present paper lies in its attempt to provide the public with some sort of linguistic illumination that enables them to identify the discursive strategies employed to deceive and control. The ability of the public to identify these manipulative tactics will make them aware of the abuse of language to dominate thought. This in turn will help them resist all forms of brainwashing and mind control.

This paper consists of 5 sections. Section 1 is the current introduction. Section 2 presents a theoretical background and some previous studies concerning mind control and Nineteen Eighty-Four. Section 3 offers the methodology used in data analysis and the theoretical framework of the study. Section 4 provides the analysis of the selected data. Section 5 presents the conclusion of the paper with some suggestions for future research.

\section{Theoretical Background and Literature}

\subsection{Critical Discourse Analysis}

Critical Discourse Analysis (CDA) focuses on the analytical study of issues related to language, power, dominance and ideology, with regard to the way language communicates ideology and encodes power. This field of study started in the late 1970's and discussed by many linguists, such as Fairclough $(1989,1995)$; Fairclough and Wodak (1997); Fairclough et al. (2003); Billig (2003); van Dijk (1993, 1996, 2000, 2001a, 2001b, 2014); Weiss and Wodak (2003); Schaffner, (2004); Wodak and Meyer (2009); Widdowson (2007), among others. CDA is defined by Widdowson (2007) as a social and political approach of analyzing language which in turn reflects ideological significance to texts by exposing the linguistic features of such texts. van Dijk (2001) states that critical discourse analysis is a form of discourse that analyzes the ways through which language, power, dominance and inequality are incorporated and reflected in political and social contexts. CDA offers a type of illumination against the oppressive use of language, and supports a way of resistance against injustice and inequalities.

van Dijk (1993) argues that CDA tries to reveal the linguistic devices in written and spoken discourse which are used to exercise power. This, in turn, helps the public differentiate between the linguistic tools which serve to illuminate and those dedicated to manipulate. The public's ability to understand the hidden motivations beyond any discursive act enables them to combat the oppressive use of language, and forces them to struggle against dictatorship and to resist inequalities.

Fairclough and Wodak (1997) view CDA to be a linguistic discipline which focuses on social problems and political issues in contemporary societies. It has therefore a socio-political dimension of addressing issues related to power and ideology. The main concern of CDA then is to show how language reflects relations of power, reproduces dominance, and communicates ideologies. This point is reinforced by Wodak and Meyer (2009) who state that the main concern of CDA is the study of social inequality that is reflected by language use. They see power to be a basic pillar in social and political life. Pardo (2001) also points out that CDA analyzes discourse and exposes relations of power abuse expressed by textual linguistic features.

van Dijk (2001a, p. 353) postulates that CDA has many types that are different from each other; the analysis of a conversational or narrative genre is quite different from the analysis of news reports in the press or political speeches in election campaigns. Each type has its own perspective which is used within the framework of CDA. Yet, the clear fact is that all types of CDA discusses the way specific discourse structures are deployed in the reproduction of social dominance whether they are part of a conversation, a narrative work, a news report, a political speech or any other genres and contexts (ibid., p. 353).

Fairclough (2010) argues that CDA analyzes discourse and investigates its elements by showing the dialectical relation between discourse and the other elements that might affect its interpretation. These elements include the internal relations of discourse, such as its lexis, syntactic structures, semantic relations and pragmatic implications that are interwoven to produce the ultimate form of a text, on the one hand; and the external relations of discourse, such as the contextual atmosphere in which a piece of discourse is produced and consumed, on the other. Fairclough's approach therefore highlights the significance of both the micro and the macro structures of texts and talk. Within the framework of this approach, CD analysts are concerned with analyzing the different argumentative relations between discourse and the other elements that affect their interpretations; be they social, economic, political, or otherwise. 
It is noticeable here that Fairclough's new approach to CDA comes to terms with his framework in which he presents a three-dimensional model for the analysis of discourse (Fairclough, 1989; 2009; 2013). The first dimension discusses the linguistic properties of texts from lexical, semantic and pragmatic perspectives. The second dimension envisions discourse as an interactional act which affects and is affected by society. The third dimension focuses on the social practices in discourse in which notions of power, dominance, and hegemony are produced, reproduced and practiced. Fairclough's model, therefore, draws a parallel with his three stages model of discourse in which he argues that any discursive act should be firstly described, then interpreted and finally explained.

Fairclough and Wodak (1997, pp. 271-280) summarize the main principles of CDA as follows:

1) CDA addresses social problems.

2) Power relations are discursive.

3) Discourse constitutes society and culture.

4) Discourse does ideological work.

5) Discourse is historical.

6) The link between text and society is mediated.

7) Discourse analysis is interpretative and explanatory.

8) Discourse is a form of social action.

According to Fairclough (1989), CDA gives great concern to the study of ideology. He sees ideologies as main pillars that can contribute in sustaining inequality relations of power. This idea has been emphasized by Fowler's (1991) argument that all aspects of linguistic expressions can encode ideological significance. Such ideologically-laden meanings can be decoded by different linguistic tools: lexical, grammatical, pragmatic, or otherwise. From the perspective of CDA, van Dijk (2001b) perceives ideology to be a particular type of social cognition that is common among specific members of one group. Ideologies then form the basis of the social representations and practices of group members including their discourse which, in turn, functions as the means of ideological production. van Dijk (ibid.) maintains that ideologies are a set of beliefs and convictions that usually pertain to groups, political or social, to defend their principles and ideas. In Nineteen Eight-Four, ideology is a main element through which the ruling Party of Oceania manipulatively uses to propagate their own beliefs, and to practice mind control over the masses.

Ideology then is a fundamental element that fosters a close connection between discourse and society (van Dijk, 1997). Ideologies are developed by dominant groups in order to "reproduce and legitimate their domination" (ibid., p. 25). van Dijk demonstrates that some strategies are used to accomplish such legitimization of domination. Among these strategies are: (a) to present domination as God-given, and (b) to persuade the dominated group to simply take such a social relation for granted (ibid., p. 25). Discourse in this approach fundamentally functions to be a tool through which ideological beliefs are manipulatively communicated in society, and thus helps produce and reproduce power, control and domination of specific groups.

\subsection{Mind Control in Nineteen Eighty-Four}

In Nineteen Eighty-Four, language plays an integral part in controlling the minds of Oceanian citizens. It is employed to dominate, oppress and control them. This linguistic manipulation takes different shapes, and is communicated by means of different CDA's strategies, such as simplification, morphologicalization and euphemism. The sole aim beyond such manipulation is to keep the masses ignorant and unconscious of the brainwashing process they are leading under a very sever dictator system. They are unable to think of the contradictions they face within Oceania, where thought is a crime.

Mind control in Nineteen Eight-Four passes through different stages; first, by banning thought, which is communicated manipulatively in the novel by the two-way screens, and the hidden microphones that spread everywhere. These are operated by the Thought Police to monitor any violations of the established rules; second, by spreading lies and employing slogans every now and then to brainwash the minds of the masses. The two elements manage to create a state of complete compliance and submission to the ruling Party; third, by falsifying history and records, which is conducted by Winston Smith, the protagonist, who attempts to alter all facts recorded from the past to make them relevant to the present Oceania. This has been executed during his work in the Ministry of Truth, Records Department; and, fourth, by indoctrinating young children at school to report to the Though Police when their parents violate any rule of the system (see Fowler, 1995; Orwell, 1999). 
Further, mind control practices continue when the Party manages to propagate the belief that every citizen in Oceania is monitored by the telescreens, and thus, everybody knows for sure that he/she is always under the watchful eyes of the Party. Additionally, the ruling Party uses new form of language (Newspeak) to replace the Oldspeak. By this way new vocabularies are introduced to fit with the Party's policies. Simplification through slogans is also employed to achieve mind control. Different slogans utilized in Oceania, such as "war is Peace", "Freedom is Slavery", and "Ignorance is Strength". Ultimately, all these tactics lead to creating domination over the minds of the masses in a way that allows them no chance of thinking or criticizing (see Hahn, 1989; Brown, 1984; Bolton, 1984).

\subsection{Related Literature}

The research conducted on Orwell's Nineteen Eighty-Four is certainly bulky. However, in the following lines, the paper goes through some more relevant studies that provide analyses for the novel from a pure linguistic point of view, particularly with regard to the theme of mind control.

Deiterle (2003) offered a purely political perspective study of Orwell's Nineteen Eighty-Four in which he concentrated on the influence of the novel on the political systems. The study firstly provided a brief summary of the novel, and then proceeded to speak about the governmental institutions and how they are influenced by the political atmosphere that is created by the novel. The study focused on the means of control used in the novel which in turn affect the different institutional bodies such as education. The most important result of Deiterle's study was that fiction has a great role in politicizing governmental institutions.

Another study that provided a linguistic study of Nineteen Eighty-Four is Luchini and García (2006). This study discussed Orwell's novel from a sociolinguistic perspective. The study traced the origins of Orwell's Problem by depicting the fictional sociolinguistic scenario presented in Nineteen Eighty-four. It analyzed the main social institutions found in the novel and showed that Orwell's novel is depicted as a symbolic model for understanding how Orwell's Problem functions in real life. The main objective of Luchini and García's study is to depict the foundations of Orwell's problem by providing a sequenced analysis of the sociolinguistic mechanisms that allowed the Party to shape the mental disposition and behavioral patterns of its subjects. One of the findings of this study clarified the effectiveness of sociological dimensions of language in creating better understanding of the status-quo.

Hama (2015) also presented a linguistic study of language as an oppressive device in Orwell's Nineteen Eighty-Four, in which he investigated the oppressive use of language as a tool of domination. Hama's study showed how language is used by the dominant authority to oppress and to exert power over the population in the country. This study adopted a stylistic and a critical discourse analysis framework in data analysis in an attempt to explore the linguistic features in some selected extracts from the novel to show how regimes oppress others by means of language. This study concluded that the totalitarian regimes manipulate language to dominate people.

Additionally, Amundsen (2015) investigated language and human rights in Nineteen Eighty-Four. This study discussed the connection between language and human rights in dystopian fiction with regard to two novels; one of them is Orwell's Nineteen Eighty-Four. The main concern of this study was to a large extent both educational and pedagogical as it attempted to shed lights on the way through which dystopian fiction can be taught to pupils in secondary schools. The study revealed that the abuse of language lead ultimately to the loss of a number of human rights in a totalitarian society.

A further relevant study was conducted by Hossain (2017), in which he stated that language is the corner stone in forming one's thoughts and deeds, as it plays a fundamental role to widen people's concepts about things around them. The study illustrated the language of power in Orwell's dystopian novel, Nineteen Eighty-Four. It focused on two aspects: the ability to do and undo from a linguistic point of view. This study also attempted to investigate the extent to which Orwell has shown the psychological impact of language on people's minds. The paper ended up with reference to great connection between linguistic treatments in 1984 and the dominance of language on people's mental procedure.

Regardless of the fact that the above studies and many other studies provided detailed study to Orwell's novel, this paper will tackle the same novel from a completely different perspective. A thorough look at the previous studies and their likes makes it clear that they deal with the novel from pedagogical, educational, political or sociological perspectives. None of these studies present a lexically-based approach to mind control strategies in the novel by adopting CDA framework; the thing which this paper tries to offer. Here lies the difference between this paper and the other studies on the same topic. 


\section{Methodology}

\subsection{Approach}

This paper analyzes mind control strategies in George Orwell's Nineteen Eighty-Four by using a lexical approach to critical discourse analysis. The paper tries to show how CDA can reveal some discursive strategies used to achieve mind control in the selected novel. CDA is concerned with the exposition of issues related to language, power and ideology with regard to the way language communicates ideology and encodes power. This field of study offers a way of understanding the role of language in the production of dominance and inequality. Its main concern is to show how discourse reflects power and asserts it.

\subsection{Corpus}

The corpus which the paper analyzes consists of one novel written by George Orwell in 1948: Nineteen Eighty-Four. Orwell's novel is one of the most popular dystopian narratives in modern English literature, in which the writer delineates a totalitarian regime that tries by all means to oppress and dominate its people. This regime employs different tools to restrict the freedom of the public. The novel under investigation consists of twenty-three chapters distributed in three parts.

\subsection{Procedure}

The analytical procedure adopted in this paper has two main stages. The first stage constitutes the process of reading the whole novel and then to mark all linguistic strategies that are employed in the discourse of the novel to produce mind control within the contextual scope of narration held between the different characters in the novel and prevailed throughout its incidents. The second stage is dedicated to reveal the CDA's strategies that are indicative in the discourse of mind control. Crucially, in the two stages the focus is on showing the extent to which CDA uncovers hidden relations of power that advocate inequality and domination, on the one side; and the connection that can be inferred from the novel as a work of fiction and similar situation in present time politics.

\subsection{Framework of Data Analysis}

There are many strategies of mind control that are employed in the novel, and are considered to be relevant in today's politics. However, the paper focuses only on the lexically-based strategies; that is, those which are entirely based on vocabulary and lexis. More specifically, the analysis focuses on three main strategies: Simplifications (through slogans, posters and captions), Euphemism (through mollification), and morphologicalization (through Newspeak).

Simplification is a strategy that is represented in the use of slogans and captions, and is totally based on the use of words. Slogans and captions are considered "a form of control" (Pinto, 2004, p. 661). They are among the tactics employed to dominate and control the public. For Lu (cited in Pinto, 2004), slogans are useful forms in the discourse of politics because they function to instigate polarized thinking towards a particular argument. The use of slogans to control aims to activate dictation and to undermine understanding among recipients, or as Corbiere puts it "slogans reflected a system of indoctrination in which memorization replaced reason" (qtd. in Pinto, 2004, p. 661). Slogans facilitate the process of mind control because they always summarize the ideology of an individual or of a group.

Euphemism is another CDA's strategy that is based on the use of favorable lexis to hide their unfavorable meanings and bad connotations. Euphemism is always employed to hide facts and to mollify lies and atrocities committed against the public. It is defined by Allan and Burridge (1991) as substituting a pleasant term for an offensive one. Euphemism is used in order to avoid embarrassment or loss of face among discourse participants. Consequently, euphemism is considered a face-saving tactic adopted in social interaction to avoid offending and harming the sensibilities of any parties involved in verbal interaction. For Olanipekun (1992), there are three characteristics of euphemism: first, the speaker's intention to make his expression relevant to the situation; second, the speaker's desire to hide undesirable meanings; and, third, as a way of control and domination. However, there is another side of using euphemism as it is not only used to save face between interlocutors, but rather to manipulate others into complete compliance to one specific argument. This manipulative dimension of the term is often used in political discourse, where powerful elites try to subjugate the masses, as is the case for the novel under investigation.

Morphologicalization is a CDA's strategy that is skillfully utilized in Nineteen Eighty-Four. This strategy is linguistically manifested in 'Newspeak', which is purely an expression of Orwell that enters the arena of critical discourse studies after the publication of the novel under investigation. Morphologicalization is based on the concept of inventing new words in a language. These new words and expressions come as a result of a process of 
combining words together (as is the case for Doublespeak); by producing words in a rapid rate of delivery in a way that makes them incomprehensible (as is the case for Duckspeak); or by inventing totally new words to replace the old ones (as is the case for Newspeak). In all its linguistic manifestations, morphologicalization is employed in the novel to sustain domination and control. The three main strategies so far will be linguistically analyzed within the framework of CDA to show how they are indicative in the production of control and dominance. This will be reflected in the analysis section below.

\section{Analysis}

\subsection{Simplification}

In Nineteen Eighty-Four (henceforth, 1984), simplification is linguistically manifested in the use of slogans and captions. Slogans are skillfully used to control the minds of the masses. Three main slogans of the Party are written in capital letters on billboards, on telescreens and on the four pyramids housing the ministries:

\section{WAR IS PEACE \\ FREEDOM IS SLAVERY \\ IGNORANCE IS STRENGTH (1984, p. 7)}

The above slogans of the ruling Party demonstrate the same syntactic structure as they constitute simple grammatical structures in the simple present tense to communicate continuity. Semantically, the first two slogans display contradictory ideas in their lexis. That is, 'war' is the opposite of 'peace' in the first slogan; and 'freedom' is the opposite of 'slavery' in the second slogan. The third slogan, however it semantically violates the idea of contradiction, it is highly indicative in sustaining the idea that being unable to understand on the part of the masses is a precondition of being safe from the contradiction they may feel if they think or have the ability to know.

The three slogans are paraphrased by Goldstein Book to carry meanings relevant to what the Party desires. Thus, the first slogan is paraphrased to mean that war is the normal condition of the new age (of Oceania), as peace was of the previous regimes. This type of paraphrase indicates that the state will be always in a state of war with other countries and opponents. This, from the Party's perspective and according to Khafaga (2017a), attempts to legalize the irrational, justify violence and institutionalize the forbidden. Likewise, the second slogan is paraphrased to communicate the idea that the pain of free choice is the clank of the chains of servitude to one's environment. The third slogan also is paraphrased to mean that knowledge is a way that takes its owners to the realm of contradiction of thought. Significantly, the employment of the three slogans functions to manipulate the masses into complete compliance to the Party without any understanding to what is happening around them since intelligibility means to think, and thought is a crime under Oceanian regime led by Big Brother.

Further, the use of posters and captions in 1984 is significant in sustaining mind control. The caption,

$$
\text { BIG BROTHER IS WATCHING YOU (1984, p. 5), }
$$

which is written under a very big poster of a person whom we know that he is the leader of the Party: Big Brother. Similar to the way of writing the three slogans above, the capitalized caption is highly indicative in sustaining the concept that every person is under control. The combination of the big poster and the caption underneath it functions to communicate the meaning of a dictatorial leader who is always there. Again, the present progressive tense by which the caption is written indicates continuity and readiness to sacrifice soul and body for the sake of the leader: Big Brother.

\subsection{Euphemism}

Many examples of euphemistic expressions are recurrently used in Orwell's 1984 to cover the sinister things in the novel in which he satirizes actual totalitarian regimes. These euphemistic terms constitute different linguistic representations in the narrative. The first idea of euphemism in the novel is clearly shown in the naming of ministries. The ministries of peace, love, plenty and truth are misleading names for the contrary purposes that are hidden beyond their literal names and meanings. They are ambivalent lies whose names hide their real activities. Consequently, we find that the 'Ministry of Peace' which is supposed to achieve peace is turned to be a 'Ministry of War'; the 'Ministry of Truth' which is responsible for arts and education is turned to be concerned with the falsification of records and history to cope with the Party's principles; the 'Ministry of Plenty' which is supposed to develop economy shifts its activities to be about economic reduction rather than economic development; the 'Ministry of Love', which is supposed to maintain law and order, becomes responsible for mental conditioning through torture. Crucially, the four ministries cease to address their real activities and are dedicated to make the opposite. This contradiction, which is communicated through euphemism, is highlighted by Orwell himself: 
The Ministry of Peace concerns itself with war, the Ministry of Truth with lies, the Ministry of Love with Torture, and the Ministry of Plenty with starvation. (1984, p. 178)

Orwell maintains that the contradictory meanings encoded in the names of the four ministries communicate the idea that power in dictator societies is gained and maintained for ever:

These contradictions are not accidental, nor do they result from ordinary hypocrisy: they are deliberate exercises in doublethink. For it is only reconciling contradictions that power can be retained indefinitely. (1984, p. 178)

It is important to mention here that the employment of euphemism in 1984 provides support for the triadic relationship between language, society and politics as presented in Orwell's novel in the sense that "the political language has to be consisted largely of euphemism, question begging, and sheer cloudy vagueness" (Wardhaugh, 1992, p. 237).

Another use of euphemism in 1984 is displayed by the use of some words and expressions whose literal meanings are shifted to convey ideological signification. Thus, the expression 'forced labor camp' becomes 'Joycamp' to hide the bitter connotation that can be grasped beyond the surface meaning. The use of euphemism here attempts to remove any bad connotations that may be attributed to the expression. Also, the word 'Ingsoc' which refers to 'Socialism' in the surface is used to manipulate in reality. A further example of the use of euphemized words to deceive and control others is the word 'vaporize', which refers to the act of non-existence to those who try to violate the rules of the Party. The use of this word, therefore, makes responsibility unknown and, thus, dissociates the state from any mischievous acts against the masses. Using euphemism ultimately aims to hide facts, to cover deception, and to sustain submission and oppression.

\subsection{Morphologicalization}

Morphologicalization, as alluded before, comprises the state of producing new words to language. In 1984, this process is clearly represented in the use of what Orwell calls 'Newspeak'. According to Orwell's novel, Newspeak is a form of language that is totally invented, organized and controlled by the Party to replace the old one (Oldspeak in the Orwellian perspective). In Orwell's words, Newspeak is used to refer to a language that is designed "to diminish the range of thought" (1984, p. 247). It is the language invented by Orwell himself to communicate the ideological ideas of socialism as seen by him. It is used in Oceania to rename things, to limit freedom and to decrease understanding, with the intention to reduce vocabulary so as to manipulate the masses.

Morphologically, Newspeak is characterized by a specific system of derivation that allows the formation of the new vocabulary needed within the ideological agenda of the Party, that is, to achieve thought control (mind control). The reason beyond Newspeak lies in the Party's policies that there are words in the old language that must be vanished since they allow the public much freedom of thought and expression. Consequently, all words that carry deep connotations are erased from Oceanian Newspeak. For example, words and phrases, such as 'bad' and 'very good' are replaced by 'ungood', 'plusgood' and 'double plusgood', respectively. All words that carry bad connotation have eliminated and replaced with others that connote positive ideas. However, the lexis 'free' is still used in Newspeak, its derivative noun 'freedom' is eradicated, allowing the public to use the former in situations that indicate their empty minds: minds are free from though. Thus, retaining some lexis from Oldspeak is due to ideologically systematic purposes.

It is worthy to mention that Newspeak attempts to reduce the number of words in the English language so as to eliminate it totally with the passage of time. The rationale beyond this, within the dictatorial realm of Oceania, is the intention to limit the degree of intelligence among people because it is believed that the higher amount of vocabulary leads to a higher state of thinking and intelligence. The Party wants to control everything and this, for the Party, will be realized by changing language to fit with the new system.

Further, reducing the words of Oldspeak in Oceania is realized through a number of inflections that are morphologically incorrect. For example, the inflectional 'ed' has been attached to all verbs in Newspeak. Thus, we meet words, such as 'drinked' instead of 'drank'; 'goed' instead of 'went'; and 'fighted' instead of 'fought', etc. Also, the inflectional 's' of the plurality has been generalized to all nouns. Again, we find plurals, such as childs, mans, etc. The inflectional rules are found in adjectives to the extent that the comparative 'er' and the superlative 'est' have been attached to all adjectives as in 'gooder' and 'goodest'.

Newspeak is also established through the generalization of the morphological rules concerning the formation of opposites and adjectives. As such, all pure opposites of words are vanished and replaced by the prefixation 'un' to indicate oppositeness. Thus, we meet a word such as 'ungood' as the opposite of 'good' rather than 'bad'. In addition, the suffix 'ful' is attached to all words to form adjectives as 'speedful'; and the suffix 'wise' is added to 
words to form adjectives as in 'speedwise'. A further type of linguistic reduction in 1984 is realized by the total omission of some words. Thus, some words are completely omitted from language, not because of facilitating communications among the people, but because they are no longer relevant to the new ideological policies of the new system in Oceania. So, 'justice', 'religion', 'democracy', 'science' and 'liberty' are all eliminated from the Newspeak.

Additionally, Newspeak is linguistically manifested in the novel through compounding. That is, a number of words are combined together to form new words that communicate ideological meaning relevant to the Party. These words include 'goodthink' to refer to natural orthodoxy; 'unperson' to indicate non-existence; 'crimethink' which means thoughtcrime; and 'crimestop' to communicate the act of stopping any crimes opposing the system. Importantly, the whole process of morphologicalization attempts to limit the degree of thought, and thus, is a tool towards controlling the minds of Oceanian people. The following table summarizes mind control strategies and their linguistic manifestations within CDA's analytical framework.

Table 1. Mind control strategies and their linguistic manifestation in 1984

\begin{tabular}{lllll}
\hline Mind Control Strategy & $\begin{array}{l}\text { Linguistic } \\
\text { Manifestations }\end{array}$ & & \\
\hline Simplification & $\begin{array}{l}\text { Slogans } \\
\text { Posters \& caption } \\
\text { Re/Naming } \\
\text { Mollification }\end{array}$ & & & \\
Newspeak & Derivation & Prefixation & \\
Morphologicalization & Inflection & Suffixation & Suffixation & un (ungood) \\
& & & ful (speedful) \\
& & & -ed verbs (fighted) \\
& & & -s/-es Nouns \\
(childs/oxes) & -er/-est adjectives \\
(gooder/goodest) & (Ingsoc) \\
& & & & Speedwise/crimethink \\
& & & Justice/liberty/democracy \\
\hline
\end{tabular}

Table 1 above clarifies the extent to which mind control is realized by means of three CDA's strategies: simplification, euphemism and morphologicalization. Simplification is linguistically manifested in the use of slogans, posters and captions. Euphemism is realized by means of naming and/or renaming things and through mollification. Morphologicalization is presented by virtue of a number of morphological processes including, derivation, inflection, coinage, compounding and reduction. Significantly, the three main strategies with their different linguistic manifestations are manipulatively used to dominate and control the minds of the masses inside Orwell's Oceania.

\section{Conclusion}

This paper attempted a critical discourse analysis of mind control strategies in George Orwell's Nineteen Eighty-Four. The analysis demonstrated that the language of the novel is manipulatively used to achieve control and dominance. Concerning the research question No. 1: what are the different CDA's strategies employed to manipulate minds in Orwell's Nineteen Eighty-Four? The paper showed that mind control is linguistically evidenced through a number of strategies, such as simplification, euphemism and morphologicalization. All of which depend totally on the ideological use of lexis. These strategies have linguistically been manifested in different tactics, including slogans and caption (simplification); naming and/or renaming things and mollification (euphemism); and derivation, inflection, coinage, compounding and reduction (morphologicalization).

With regard to the research question No. 2: to what extent does CDA reveal hidden tactics of power abuse and mind control in the novel under investigation? The analysis clarified that CDA proves useful as a theoretical and analytical approach of analyzing language in revealing the different mechanisms employed in the discourse of the novel to control minds. The analysis displayed the extent to which CDA linguistically relates issues of power, dominance and control to social structures and ideological processes as it perceives language as a site of power conflict determined by the dexterous choices of its users.

In terms of the research question No. 3: to what extent is CDA theoretically relevant to the study of mind control 
in the selected novel? The analysis showed that any literary text that undergoes a linguistic analysis within the framework of CDA is ready to be deconstructed in order to discover new meanings; an idea which, for Khafaga (2017b), supports the assumption that CDA is perceived as a deconstructive, reader-oriented model of analyzing texts. CDA is concerned with the analysis of political discourse to reveal hidden power relations as well as the extent to which language is abused for the purpose of manipulating attitudes and reshaping behavior for the benefit of the dominant ideology. This in turn reflects the relevance of CDA to the analysis of issues, such as power, dominance, hegemony and control in texts and talk. These issues are the dominant themes in dystopian fiction, as is the case for 1984. Finally, this paper suggests the application of other levels of linguistic analysis (e.g. the semantic level, the pragmatic level, and the cognitive level) to Orwell's Nineteen Eighty-Four. This could reveal different results other than those approached here.

\section{Acknowledgements}

This research project was supported by the Deanship of Scientific Research at Prince Sattam bin Abdulaziz University under the research project No. 2019/02/9982.

\section{References}

Allan, K., \& Burridge, K. (1991). Euphemism and dysphemism. Language used as shield and weapon. Oxford: Oxford University Press.

Amundsen, V. (2015). Language and human rights in Nineteen Eighty-Four and Never Let Me Go. MA Thesis, the Arctic University of Norway: Norway.

Billig, M. (2003). Critical discourse analysis and the rhetoric of critique. In G. Weiss, \& R. Wodak (Eds.), Critical discourse analysis: Theory and interdisciplinarity (pp. 35-46). Palgrave Macmillan Ltd. https://doi.org/10.1057/9780230514560_2

Bolton, W. F. (1984). The language of 1984. Orwell's English and ours. Basil Blackwell Publisher Limited.

Brown, A. (1984). Examining Orwell: Political and literary values in education. In C. Norris (Ed.), Inside the myth. Orwell: Views from the left (pp. 39-61). London: Lawrence and Wishart.

Deiterle, C. (2003). George Orwell' 1984 and its implications on the political system of the GDR. Germany: GRIN Verlag Publishing.

Fairclough, N. (1995). Critical discourse analysis: The critical study of language. London \& New York: Longman.

Fairclough, N. (2009). A dialectical-relational approach. In R. Wodak, \& M. Meyer (Eds.), Methods of critical discourse analysis (pp.162-186). Thousand Oaks: Sage.

Fairclough, N. (2010). Language and power. London \& New York: Longman.

Fairclough, N. (2013[1989]). Language and power (2nd ed.). London \& New York: Longman.

Fairclough, N., Pardo, S., \& Szerszynski, B. (2003). Critical discourse analysis and citizenship. In A. Bora, \& H. Hausendorf (Eds.), Constructing citizenship (pp. 1-17). John Benjamins.

Fairclough, N., \& Wodak, R. (1997). Critical discourse analysis. In T. van Dijk (Ed.), Discourse as social interaction: Discourse studies: A multidisciplinary introduction (Vol. 2, pp. 258-284). Sage Publications.

Fowler, R. (1991). Critical linguistics. In M. Kirsten (Ed.), The linguistic encyclopedia. London \& New York: Routledge.

Fowler, R. (1995). The language of George Orwell. Macmillan Press Ltd. https://doi.org/10.1007/978-1-349-24210-8

Hahn, D. F. (1989). Political language: The art of saying nothing. In L. William (Ed.), Beyond Nineteen Eighty-Four: Doublespeak in a post-Orwellian age (pp. 111-120). The National Council of Teachers of English.

Hama, B. S. (2015). Language as an oppressive device in Orwell's 1984. International Journal of Humanities and Cultural Studies, 2(1), 265-277.

Hodge, B., \& Fowler, R. (1979). Orwellian linguistics. In R. Fowler, B. Hodge, G. Kress, \& T. Trew (Eds.). Language and control (pp. 6-25). London: Routledge. https://doi.org/10.4324/9780429436215-1

Hossain, M. (2017). Language as the device for psychological manipulation in George Orwell's Nineteen Eighty-Four: a psycholinguistic analysis. European Journal of English Language and Linguistics Research, 
$5(8), 25-31$.

Khafaga, A. (2017a). Linguistic manipulation of political myth in Margaret Atwood's The Handmaid's Tale. International Journal of English Linguistics, 7(3), 189-200. https://doi.org/10.5539/ijel.v7n3p189

Khafaga, A. (2017b). Discourse interpretation: A deconstructive reader-oriented approach to critical discourse analysis. International Journal of Applied Linguistics \& English Literature, 6(2), 138-146. https://doi.org/10.7575/aiac.ijalel.v.6n.2p.138

Luchini, P., \& García, A. (2006). Turning to Orwell to understand Orwell's problem: A sociolinguistic view. The Reading Matrix, 6(1), 97-105.

Olanipekun, O. (1992). Euphemism as a Yoruba folkway. African Languages and Cultures, 5(2), 189-202. https://doi.org/10.1080/09544169208717754

Orwell, G. (1949). Nineteen Eighty-Four. New York: Signet Classics.

Orwell, G. (1999). Politics and the English Language. In S. Hirschberg, \& T. Hirschberg (Eds.), Reflections on language (pp. 500-511). Oxford: Oxford University Press.

Pardo, M. L. (2001). Linguistic persuasion as an essential factor in current democracies: Critical analysis of the globalization discourse in Argentina at the turn and at the end of the century. Discourse \& Society, 12(1), 91-118. https://doi.org/10.1177/0957926501012001006

Pinto, D. (2004). Indoctrinating the youth of post-war Spain: A discourse analysis of a Fascist Civics textbook. Discourse \& Society, 15(5), 649-667. Sage Publications. https://doi.org/10.1177/0957926504045036

Schaffner, C. (2004). Political discourse analysis from the point of view of translation studies. Journal of Language and Politics, 3(1), 117-150. https://doi.org/10.1075/jlp.3.1.09sch

van Dijk, T. A. (1993). Principles of critical discourse analysis. Discourse \& Society, 4(2), 249-283. https://doi.org/10.1177/0957926593004002006

van Dijk, T. A. (1996). Discourse, power and access. In C. Caldas-Coulthard, \& M. Coulthard (Eds.), Texts and practices: Readings in critical discourse analysis (pp. 84-104). London \& New York: Routledge.

van Dijk, T. A. (Ed.) (1997). Discourse as interaction in society. In Discourse as social Interaction: Discourse studies: A multidisciplinary introduction (Vol. 2, pp. 1-37). Sage.

van Dijk, T. A. (2000). On the analysis of parliamentary debates on immigration. In M. Reisigl, \& R. Wodak (Eds.), The semiotics of racism: Approaches to critical discourse analysis (pp. 85-103). Vienna: Passagen Verlag.

van Dijk, T. A. (2001a). Critical discourse analysis. In D. Schiffrin, D. Tannan, \& H. Hamilton (Eds.), The handbook of discourse analysis (pp. 352-392). Blackwell.

van Dijk, T. A. (2001b). Discourse, ideology and context. Folia Linguistica, 35(1-2), 11-40. https://doi.org/10.1515/flin.2001.35.1-2.11

van Dijk, T. A. (2014). Discourse and knowledge: A sociocognitive approach. Cambridge: Cambridge University Press. https://doi.org/10.1017/CBO9781107775404

Wardhaugh, R. (1992). An introduction to sociolinguistics. Blackwell Publishers.

Weiss, G., \& Wodak, R. (Eds.) (2003). Critical discourse analysis: Theory and interdisciplinarity. Palgrave Macmillan Ltd. https://doi.org/10.1057/9780230288423

Wodak, R., \& Meyer, M. (Eds.) (2009). Methods of critical discourse analysis. London: Sage.

\section{Copyrights}

Copyright for this article is retained by the author, with first publication rights granted to the journal.

This is an open-access article distributed under the terms and conditions of the Creative Commons Attribution license (http://creativecommons.org/licenses/by/4.0/). 